\title{
Pricing Linkage between Islamic Banking and Conventional Banking: The Case of Bangladesh
}

\author{
Sarwar Uddin Ahmed ${ }^{1}$, Md. Ashikur Rahman ${ }^{2}$, Samiul Parvez Ahmed ${ }^{3 a}$, G. M. Wali Ullah ${ }^{4}$ \\ 1,2,3,4 Independent University, Bangladesh (IUB),Dhaka,Bangladesh
}

\begin{abstract}
Islamic banking is based on profit and loss mechanism where the use of interest is prohibited. Unlike conventional banks, these banks do not charge a specific rate of interest, rather provides financing in exchange for profit sharing. However, there are studies claiming that, in practice, Islamic banking is same as conventional banking with regard to the use of interest. It is also claimed that, Islamic deposits are not interest-free, but are closely attached to conventional deposits. On this background, the objective of this study is to examine the relationship between pricing in Islamic banks vis-à-vis conventional banks by taking the case of Bangladesh. We have used monthly data during the period of 2009-2013. The findings of the study showed that, there is no statistically significant difference between the monthly average lending rates of Islamic banks and conventional banks. However, there is significant difference between deposit rates. The existence of causal relationship was inconclusive, and requires further analysis.
\end{abstract}

Keywords: Islamic banking, conventional banking, pricing, profit and loss sharing, Bangladesh

(C) 2013 Published by SSBFNET

\section{Introduction}

During the past five decades, Islamic banking, widelyknown as "interest free" banking, is growing exponentially in terms of size, number of institutions and participants. This growth is accounted for by the interest of both Muslims and non-Muslims markingits presence in more than 70 countries of the world (Iqbal and Molyneux, 2005; Chong and Liu, 2005; Khan 2010). It is to be noted that the accumulation of "Islamic assets", and astounding growth rate ${ }^{\mathrm{c}}$ of Islamic Banking assets over the past few decades had significant impact in global finance (Khan 2010) and it is anticipated that the momentum would not cease in near future, rather the growth rate of Islamic banking would sustain at the current rate in years to come ${ }^{d}$. Having indentified this fundamental change in banking sector, major conventional banks are now branching out to Islamic banking services besides their conventional banking.

\footnotetext{
${ }^{a}$ Corresponding author: Samiul Parvez Ahmed, Tel.: +88 (0) 1780008844

b Globally, the total "Islamic assets" was US $\$ 900$ billion in 2011 (Financial Times, 2011).

${ }^{c}$ During 1995 to 2004, the Islamic Banking assets had experienced growth rate of 15\% p.a. (Benaissa et. al. 2005:1).

${ }^{d}$ Recent industry estimates show that Islamic banking is expected to grow at the rate of $15 \%$ per annum (Chong and Liu, 2005).
} 
Since, the first modern Islamic bank established in 1975 in the United Arab Emirates named as the Dubai Islamic Bank, many other countries subsequently embraced the Shariah ${ }^{\mathrm{e}}$ principle to their banking system. Currently, in few countries (e.g. Iran, Sudan, and Pakistan) Islamic financial principles (Shariah based financial system) are explicitly practiced as single mode for conducting banking (Hearn et al. 2012); however, Islamic banking co-exists with conventional banking in other countries; e.g. Bahrain, Bangladesh, Egypt, Indonesia, Jordan, Malaysia. Among the countries having Islamic banking, Bahrain is commonlyconsidered as the Muslim world's money centre where, according to Bahrain Monetary Agency, Islamic bank assets had 111\% annual growth rate between 1998 and 2005 whereas conventional banking had an annual average growth rate of only 6\% (Khan 2010:805). Interestingly, the Shariah based banking is not restricted within the Islamic world these days rather, it has expanded within the nonMuslim countries as well. Islamic Bank of Britain becomes the first bank licensed by a non-Muslim country. In addition, globally, "Citibank, ABN Amro, Bank of America, HSBC, Standard Chartered, and the Union Bank of Switzerland, either have Islamic Banking subsidiaries or offer Islamic financial products to their customers" (Khan 2010:805).

With the rapid growth of Islamic banks, there are different arguments trying to clarify the progression. Some argue that worldwide Islamic resurgence since the late 1960s has triggered the growth. Others argue that factors such as religious belief, prohibition of interest, cost and benefits offered by the banks, banking efficiency, location, service quality, etc. are influencing customers to go for Islamic banking and thus contributing towards the growth (Omer, 1992; Ahmad and Haron 2002; Mokhlis et al., 2009; Masood and Bora, 2009; Rashid et al. 2009; Khattakand Rehman, 2010; Thambiah et al., 2010; and Rehman and Masood, 2012). According to Omer (1992), Metwally (1996), Al-Sultan (1999)Khattak and Rehman (2010); Thambiah et al. (2010); and Rehman and Masood (2012) the single most commonly identified factor motivating customers to go for Islamic Banking is religious factor or religious belief. This belief says that, Muslims need to go for Shariah based banking mechanism that imposes a range of prohibitions (e.g. receiving interest rate or riba, gambling or gharar); and specific directions for Islamic banking system (e.g. "PLS" or "Profit-and-Loss Sharing" agreements $\left.{ }^{f}\right)($ Gheeraert 2014).

Now, in relation to wider debates about various features (e.g. interest free banking, PLS agreement) of Shariah based banking, question arises whether or, to what extent the Islamic banking is unique in its characteristics? Widely the critics of Islamic bankingargue that the Shariah based banking is an Islamic ideology that many banks promise to follow, but, in reality, they do not.

Thus, in order to explore the debates of the Shariah based banking from empirical point of view, this article critically examined interest free banking or PLS agreement of Shariah based banking in comparison to conventional banking. Particularly, this particular study attempted to explore this issue by examining the relationship between deposit and loan pricing in Islamic banks and conventional banks. Wehave narrowed down the focus to Bangladesh, where a well-

\footnotetext{
e Sharia law is the binding set of principles that govern the economic, social, ethical and religious aspects of Islamic society (Iqbal, 1997), commonly known as Islamic Law

The theory of Shariah based banking and PLS is discussed later.
} 
established Islamic banking has developed side-by-side with a conventional banking system. The dual banking system in Bangladesh, in particular, provides a unique opportunity for us to compare Islamic banking pricing practice with those of conventional banking.

\section{Literature Review}

\subsection{Shariah Based Banking (Islamic Banking)}

The theoretical ideology of Shariah (Islamic Laws) complianteconomic activities (where banking is a sub part) arebased on the Islamic principles which are proposed by the Quran (Muslims' Holy Book) and various Hadith ${ }^{\mathrm{g}}$ and Sunnah $^{\mathrm{h}}$ (Asutey, 2007). It is mandatory (not a choice) for all Muslims to follow an Islamic financial system which is established on and guided by the principles of the Shariah (Iqbal, 1997). Theoretically,Shariah based banking, also known as Islamic banking,is different from the conventional banking system to a greater extent. Particularly, Shariah based banking prohibits the use of interest (riba); is pillared by the profit and loss sharing (PLS) mechanism (also known as Mudarabah); and “... thus risk-sharing, on both the liability and asset side and posits that all transactions have to be backed by a real economic transaction that involves a tangible asset" (Beck et. al. 2012:433). In other words, the assets and liabilities of Islamic banks are integrated in the sense that borrowers share profits and losses with the banks, which in turn share profits and losses with the depositors under the PLS paradigm.Apart from the stated prohibitions, according to the Shariah based banking, there are few other restrictions/guidelines as well; e.g. Shariahbased banking does not allow speculation (Gheeraert, 2014) and, thus, involvement with options and other derivatives are banned; restricts banks from doing certain businesses that deals with the products/activities that are banned in the Quran (e.g. alcohol, pork, gambling); and, as a guideline, Shariahbased bankingadvocates that all financial activities/transactions must involve real economic activities (Bechat.el. 2012; Khan, 2010).It is apparent that the Shariah based banking have several principles that the Islamic banks need to comply, however, as the use of interest is inherent, directly or indirectly, within all financial activities, 'interest-free' operations have become the fundamental issue for any bank claimingitself as 'Islamic' (Khan, 2010). The Islamic scholars are also more intrigued by the role of the PLS agreement as it is the major fundamental distinguishable factor that the Muslimsconsider while choosing Islamic banking in comparison to conventional banking.

\footnotetext{
g These are values, norms, rituals \& customs that are described by the prophet Mohammed (PBUH) and Muslims are to practice these in their life.

${ }^{h}$ Life experiences of the prophet Mohammed (PBUH) and Muslims are to follow them in their life.
} 
It is true that the interest free banking proposition of Islamic banking apparently conflicts to the fundamentals of finance theories as it ignores the time value of money concept; but, instead, Islamic finance emphasizes "return on capital" which largely depends on the activities or ventures that is financed (Ariss, 2010). To be more specific, the return on capital only tuned with the risks of the ventures/activities (time value of money is apparently ignored) (Ariss, 2010); however, implicitly, the "risk" give proxy for the time as well. As part of the interest free or PLS agreement, Islamic banks directly participate in clients business as partner which is commonly known as Musyarakah or, joint ventures (Bakar, 2010). The joint venture approach or risk sharing mechanism of Islamic banking more competent to deal external shocks because the banks' financing losses are partially absorbed by the depositor's advocates of Islamic banking, thus, it is widely argued that Islamic banks are theoretically better poised than conventional banks (Khan and Mirakhor, 1989; Iqbal, 1997). According to Chopra (1992) and Mills and Presley (1999), the risk-sharing features of PLS paradigm, in theory, allows Islamic banks to lend on a longer term basis to projects with higher risk-return profiles and, thus, to promote economic growth. In many cases, a comparison of financial performance of Islamic and conventional banks has found that Islamic banks are superior to the conventional banks (Safiullah, 2010).

Moreover, the PLS paradigm subjects Islamic banks to greater market discipline. For example, Islamic banks are required to put in more effort to distinguish good customers from bad ones because they have more to lose than conventional banks. To ensure truthful reporting of profit and losses the banks also need to monitor their investments and borrowers more closely. Furthermore, Islamic bank depositors are required to choose their banks more carefully and to monitor the banks more actively to ensure that their funds are being invested prudently. Khan(1986) argues that a primary advantage of PLS banking is that it leads to a more efficient allocation of capital because the return on capital and its allocation depend on the productivity and viability of the project.

\subsection{Contemporary Debates of the ShariahBased Banking}

The application of the Shariah based banking activities can be traced back to 1930s, but its practical execution came on a much later period. The first official attempt to practice Islamic banking can be observed through the establishment of MitGhamr Savings Bank in Egypt in 1963(Chong and Liu, 2005). Afterwards, the modern Islamic finance widened mainly in the South East Asia and the Middle East where the first modern Islamic bank established in 1975 in the United Arab Emirates named as the Dubai Islamic Bank (Gheeraert 2014). According to World Bank (2006), Malaysia constitutes the biggest market for Islamic banking in the word. Besides Malaysia, Bahrain is also becoming regional hub for Islamic finance (Ariss, 2010). In Bangladesh, Islamic Bank Bangladesh Limited is the first Islamic bank, established in 1983.

Even though, globally, various Islamic banks claim to follow the Islamic laws within their banking system, there are wider arguments regarding their practical applications(Chong and Liu 2005, Khan 2010).According to the study of Chong and Liu (2005),conducted on Malaysia, showed that Islamic banking is same as conventional banking with regard to the use of interest. In this study, it was also claimed that, Islamic deposits are not PLS based, i.e., interestfree, but are closely attached to conventional deposits.In line with the comparative study between Islamic and 
conventional banking system Khan (2010:806) also assert that the Islamic Banking and Finance (IBF) "is merely a change of terminology (e.g., substituting 'profit rate' or 'markup rate' for 'interest rate') in what is essentially a standard debt contract".

From a slightly different perspective Beck et al.(2013) found that the business model (in terms of risk taking, efficiency and stability) of the Islamic bank is not too different than that of the conventional bank. However, they argue that, to certain extent, Islamic banking, in comparison to conventional banking, has higher asset quality and is better capitalized. Similarly, Ariss (2010:101) concludes from her study that the "Islamicbanks allocate a greater share of their assets to financing activities compared to conventional banks, and they are also better capitalized". Otheradvocates of Islamic finance also highlight that, apart from the conventional banking, Islamic Finance/Banking has distinguishable features that play positive role in the economy at large. For example, Gheeraert (2014) found from his study that the Islamic banking has a positive impact in developing overall banking sector of a nation. He also added that Islamic banking does not create crowding out effect to conventional banking sector, rather they complement each other. In another study Beck et. al. (2013) found that, irrespective of few shortcomings, "Islamic banks perform better during crises in terms of capitalization and asset quality and are less likely to disintermediate than conventional banks."(Beck et. al. 2013:445). Moreover, their study results showed that the “...higher capitalization and better asset quality have helped Islamic banks outperform conventional banks during the latest crisis.” (Beck et. al. 2013:445).

From a slightly different view, a study conducted by Hasan and Dridi (2010) found that the Islamic banking showed better resilience in the early stage of the recent financial crisis compare to the conventional banking; however, at later stage (in 2009), the Islamic banks fail to beat the conventional banks in terms of profitability measures. This phenomenon was partly addressed by the Shamshad Akhtar in her speech in 2009 in Rome, Italy. She asserted that the early stage resilience of the Islamic banking to the financial crisis was accounted for their higher dependency to the real estate sector and limited stake in equity based transactions (Bourkhis and Nabi, 2013).

These divergences in research findings and/or arguments regarding the theoretical and practical stances of Islamic finances or Islamic banking in comparison to conventional banking are far from being resolved. Hence, in the light of the contemporary debates about the Islamic banking, this article investigates one of the major characteristics of Islamic banking, "interest free" banking or PLS agreement, in comparison with the conventional banking, and tried to reach to a conclusion to the rising issue - whether or to what extent the Islamic banking is different from that of the conventional banking?

\footnotetext{
'The Ex-Vice-president of the World Bank for MENA in her speech during the "Symposium on Islamic Finance in Roma: Developments in MENA region”, Bank Italia, Rome, Italy, November, 11 th, 2009.
} 


\section{Research and Methodology}

3.1 Data

This study aims to fulfill the research objective by taking the case of Bangladesh. The Bangladeshi banks were classified into interest-based conventional banks and sharia-based Islamic banks. Monthly time-series data were collected on lending and deposit rates of both of these categories of banks on term loan, working capital loan, fixed deposit, and savings deposit from Bangladesh Bank sources (BB, 2013). The sampling period covered data from January 2009 to May 2013. The sample size was 53 for each series (See Appendix for the details).

\subsection{Methods}

The associations between lending and deposit rates of conventional and Islamic banks were analyzed initially through graphical time-series analysis and correlogram. Relationships between the variables were analyzed through Z-test. Lastly, to verify the short run dynamics and long run relationship between conventional deposit rates and Islamic investment rates, Granger Causality test was conducted.

Originally, the Granger causality test (1969) was developed to analyze the effect of one time series variable on to another. It is based on the following two principles:

1. The cause of the incident happens prior to the effect

2. The causal time series contains unique information about the effect series, which is not available elsewhere.

Among these two principles, the first one is universally accepted and adopted. The second principle however, is more restrained in nature and requires some adjustment (Liu and Bahadori, 2012). In simple form, Granger causality test seek to answer questions i.e. changes in any variable y1 leads to changes in another variable y2. This argument is extended to the point that, if y1 causes $y 2$, lags of y1 should be significant for $y 2$. If this is the case but not vice versa, there exists 'unidirectional causality' from y1 to y2. If lags of both sets are found to be significant, then both these variables have 'bi-directional causality' with each other (Brooks 2008).

\section{Findings}

\subsection{Time-series Plotting}

Monthly time-series data of conventional vis-à-vis Islamic banks on term loan, working capital loan, fixed deposit, and savings deposit are plotted in Figs. 1 to 4 . From Fig. 1 we can see that, for term loans the lending interest rates of conventional banks and investment rates of Islamic banks are following the same trend. In most of the cases the rates for Islamic banks are higher than the rates of the conventional banks. The same trend is also evident in case of working capital loans (see Fig.2). With regard to deposits, rates for both conventional and Islamic banks are following the same trend, while the rate for the latter is higher in most of the cases (see Fig.3). However in case of savings 
deposit the scenario reverses. Although both form of banks follows the same trend, the rates for the Islamic banks are lower than those of the conventional banks (see Fig.4).

\subsection{Descriptive Statistics}

Descriptive statistics for the eight variables are summarized in Table 1. From the table it can be seen that, the mean of the term loan lending rate for conventional banks is 13.34 percent, while for Islamic banks it is 13.63 percent. The correlation coefficient between the two is high as 0.92 . The same pattern can also be seen for the working capital rates and fixed deposit rates, where the correlation coefficient is 0.97 and 0.91 , respectively. However the depiction changes for the savings deposits. The correlation coefficient between the savings deposit rates of conventional and Islamic banks is low as 0.35 . We can expect a very high degree of positive relationship between term loan, working capital loan and fixed deposit rates of conventional and Islamic banks.

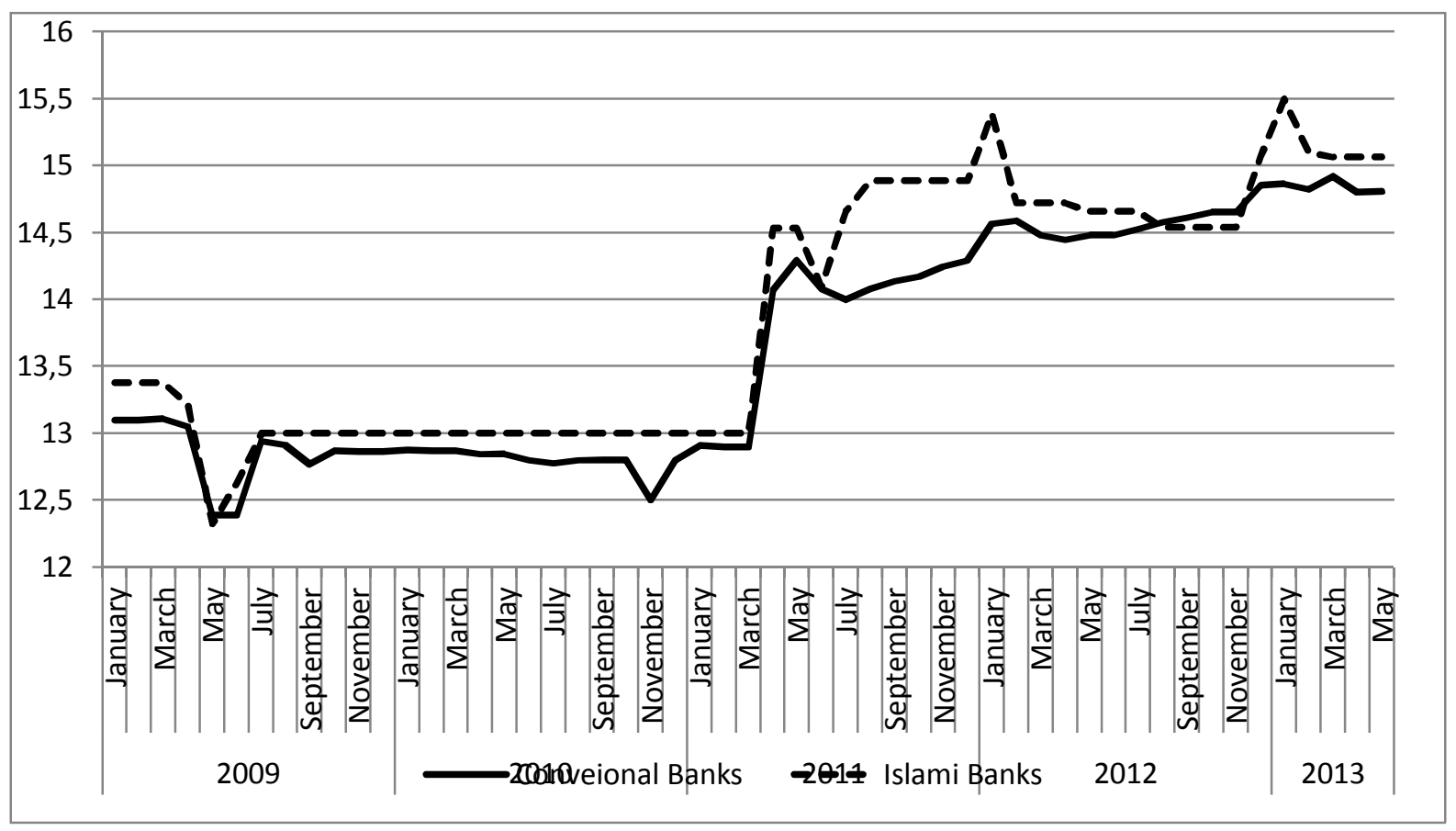

Figure 1. Term loan rates: Conventional Banks versus Islamic Banks 


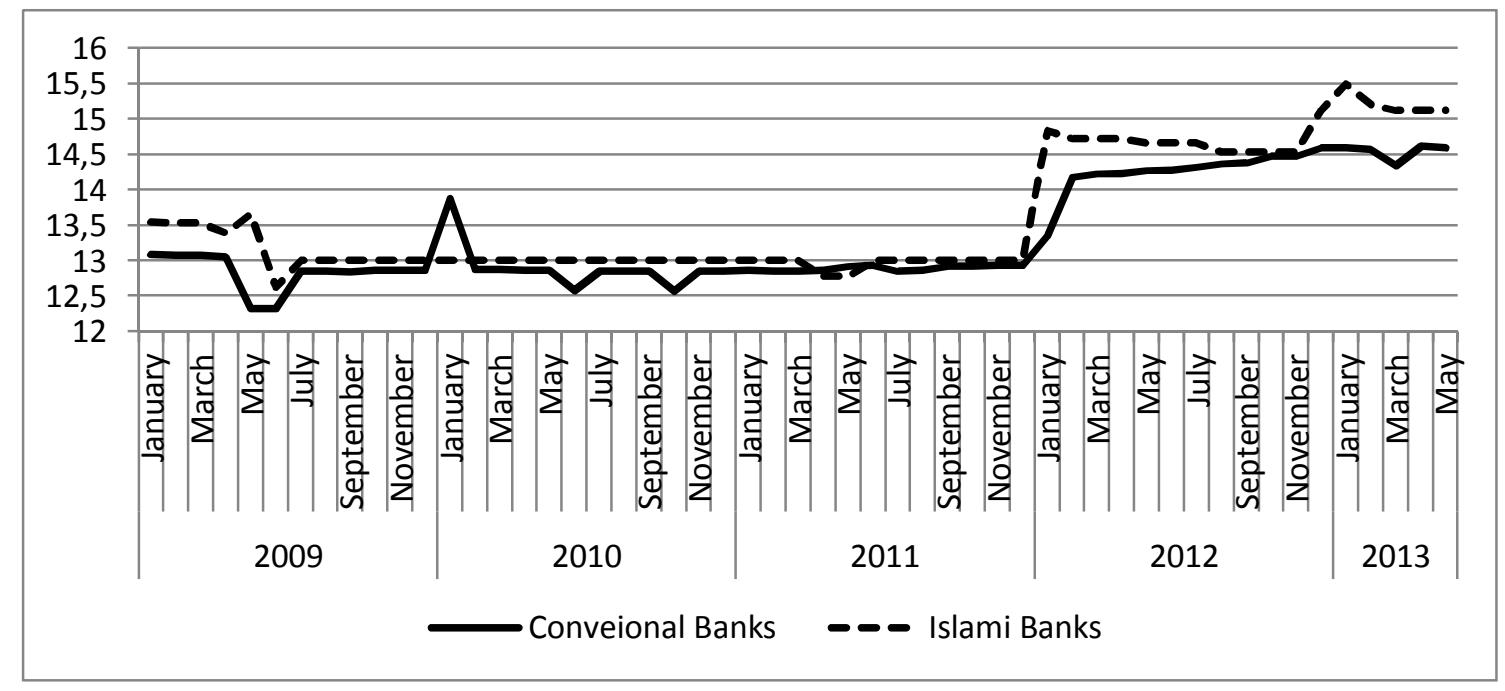

Figure 2. Working capital loan rates: Conventional Banks versus Islamic Banks

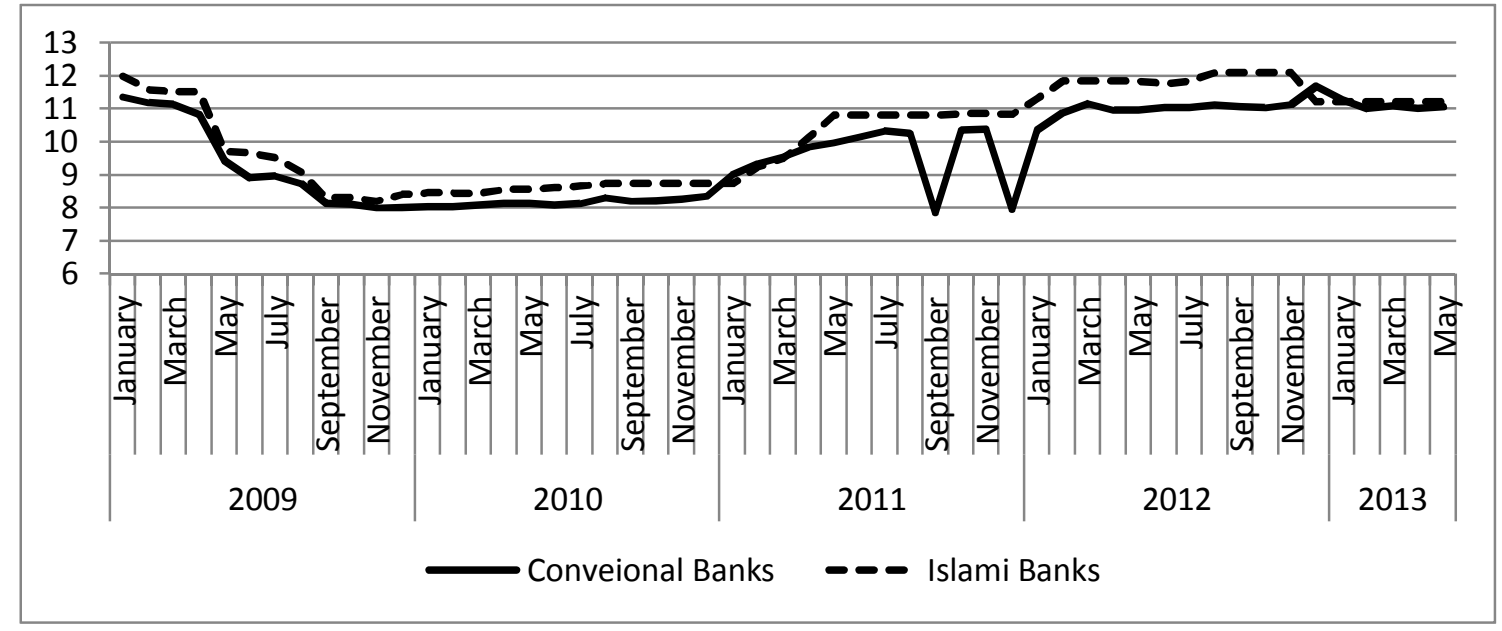

Figure 3. Fixed deposit rates: Conventional Banks versus Islamic Banks

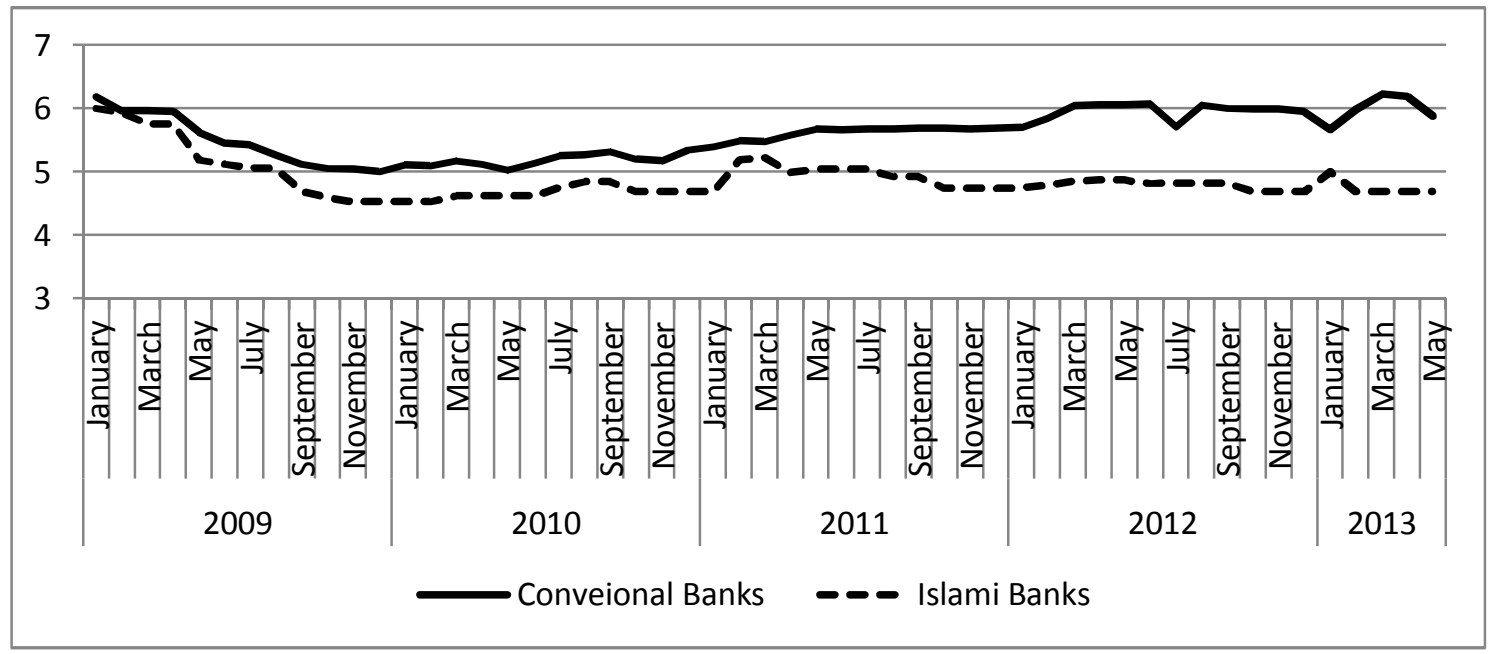

Figure 4. Savings deposit rates Conventional Banks versus Islamic Banks 
Table 1: Descriptive Statistics

\begin{tabular}{|c|c|c|c|c|c|c|}
\hline Variables & & $\mathrm{N}$ & Mean \% & Min. $\%$ & Max.\% & S.D. \\
\hline $\begin{array}{l}\text { Term loan rates: Conventional } \\
\text { Banks }\end{array}$ & TLCB & 53 & 13.34 & 12.31 & 14.62 & 0.74 \\
\hline $\begin{array}{l}\text { Working capital loan rates: } \\
\text { Conventional Banks }\end{array}$ & WCCB & 53 & 13.64 & 12.39 & 14.92 & 0.86 \\
\hline $\begin{array}{l}\text { Fixed deposit rates: Conventional } \\
\text { Banks }\end{array}$ & FDCB & 53 & 9.69 & 7.85 & 11.70 & 1.32 \\
\hline $\begin{array}{l}\text { Savings deposit rates: Conventional } \\
\text { Banks }\end{array}$ & SBCB & 53 & 5.49 & 5.00 & 6.22 & 0.85 \\
\hline
\end{tabular}

\begin{tabular}{|c|c|c|c|c|c|c|c|}
\hline \multicolumn{8}{|c|}{ Descriptive Statistics (cont...) } \\
\hline Variables & & $\mathrm{N}$ & Mean $\%$ & Min. $\%$ & Max.\% & S.D. & $\begin{array}{l}\text { Correlation } \\
\text { Coefficient }\end{array}$ \\
\hline $\begin{array}{l}\text { Term loan rates: Islamic } \\
\text { Banks }\end{array}$ & TLIB & 53 & 13.63 & 12.63 & 15.5 & 0.88 & 0.92 \\
\hline $\begin{array}{l}\text { Working capital loan rates: } \\
\text { Islamic Banks }\end{array}$ & WCIB & 53 & 13.89 & 12.33 & 15.50 & 0.94 & 0.97 \\
\hline $\begin{array}{l}\text { Fixed deposit rates: Islamic } \\
\text { Banks }\end{array}$ & FDIB & 53 & 10.25 & 8.21 & 12.09 & 1.38 & 0.91 \\
\hline $\begin{array}{l}\text { Savings deposit rates: } \\
\text { Islamic Banks }\end{array}$ & SBIB & 53 & 5.34 & 4.53 & 6.56 & 1.26 & 0.35 \\
\hline
\end{tabular}

\subsection{Results of Z Test}

In order to test whether the difference in the rates of term loan, working capital loan, fixed deposit and savings deposit between conventional and Islamic banks are statistically significant or not, Z-test has been conducted.

The results of the Z-tests are summarized through Table 2 to 5 . Table 2 shows the results of the difference of means of term loan lending rates between conventional banksvis-à-visIslamic banks. From the table we can see that the sample mean of investment rates in Islamic banks arehigher than the lending rates of conventional banks. The Z- statistic and p-value indicates that the difference between rates of these two categories of banks are not statistically significant $(\mathrm{p}=0.08)$, and leads us not to reject the null hypothesis that there is nodifference between them.

Table 2. Lending interest ratesversus investment rates in term loans

\begin{tabular}{lll}
\hline & Conventional Banks & Islamic Banks \\
\hline Sample Size (valid N) & 53 & 53 \\
Mean & 13.34 & 13.62 \\
S.D. & 0.74 & 0.88 \\
Z-test results: & & 0.28 \\
Difference in sample means & & -1.79 \\
Z-Test Statistic & & 0.08 \\
P-Value & & \\
Decision: Do not reject the null hypothesis & & \\
\hline \hline
\end{tabular}


The results of the difference of means of working capital loan lending rates between conventional banksvis-àvisIslamic banksare summarized in Table 3.From the table we can see that the sample mean of investment rates in Islamic banks arehigher than the lending rates of conventional banks. The Z- statistic and p-value indicates that the difference between rates of these two categories of banks are not statistically significant ( $\mathrm{p}=0.16$ ), and leads us not to reject the null hypothesis that there is nodifference between them.

Table 3: Lending interest ratesversus investment rates in working capital loan

\begin{tabular}{lll}
\hline & Conventional Banks & Islamic Banks \\
\hline Sample Size (valid N) & 53 & 53 \\
Mean & 13.64 & 13.88 \\
S.D. & 0.86 & 0.93 \\
Z-test results: & \multicolumn{2}{l}{} \\
Difference in sample means & \multicolumn{2}{l}{} \\
Z-Test Statistic & & -1.39 \\
P-Value & & 0.166 \\
Decision: Do not reject the null hypothesis & \\
\hline \hline
\end{tabular}

The results of the difference of means of fixed deposit rates between conventional banksvis-à-visIslamic banks are summarized in Table 4.From the table we can see that the sample mean of deposit rates in Islamic banks are higher than the rates of conventional banks.The Z- statistic and p-value indicates that the difference between rates of these two categories of banks are statistically significant ( $\mathrm{p}=0.04$ ), and leads us to reject the null hypothesis that there isno difference between them.

Table 4:Fixed Deposit Interest Rates

\begin{tabular}{lll}
\hline & Conventional Banks & Islamic Banks \\
\hline Sample Size (valid N) & 53 & 53 \\
Mean & 9.69 & 10.25 \\
S.D. & 1.32 & 1.38 \\
Z-test results: & & 0.56 \\
Difference in sample means & & -2.13 \\
Z-Test Statistic & & 0.04 \\
P-Value & & \\
Decision: Reject the null hypothesis &
\end{tabular}


The results of the difference of means of savings deposit rates between conventional banksvis-à-visIslamic banks are summarized in Table 5.From the table we can see that the sample mean of deposit rates in Islamic banks are lower than the rates of conventional banks.The Z- statistic and p-value indicates that the difference between rates of these two categories of banks are statistically significant $(\mathrm{p}=0.00$ ), and leads us to reject the null hypothesis that there isno difference between them.

Table 5: Savings Deposits Rates

\begin{tabular}{lll}
\hline & Conventional Banks & Islamic Banks \\
\hline Sample Size (valid N) & 53 & 53 \\
Mean & 5.60 & 4.91 \\
S.D. & 0.37 & 0.41 \\
Z-test results: & & \\
Difference in sample means & & 0.69 \\
Z-Test Statistic & & 9.13 \\
P-Value & 0.00 \\
Decision: Reject the null hypothesis & \\
\hline \hline
\end{tabular}

\subsection{Results of Granger Causality test}

The Granger causality test was conducted in the monthly data set of this research to determine if changes in any of the loan rates of conventional banking requires adjustments in the Islamic investment rates and vice versa. The results of the pair-wise Granger Causality test between the different deposit and investment rates of conventional and Islamic banking is summarized in Table 6. Findings indicate that for some of the four matched cases, researchers fail to reject the null hypothesis. It reveals that there is Bi-directional Granger Causal relationship present between the Term Loans of both different banking systems at $10 \%$ significance level. However, there was no other Bi-directional causality found in the loan rates of different banking systems. Though some unidirectional causal relationship existed between different banking systems, ultimately the result was inconclusive in determining dominance of either systems. These empirical evidences on the limited time series data failed to suggest that, interest rates set in Conventional banking determine Islamic banking rates in Bangladesh. 
Table 6: Pair-wise Granger Causality Test

\begin{tabular}{|l|c|l|}
\hline Null Hypothesis (H0) & P-value & Decision Rule $(\alpha=10 \%)$ \\
\hline TERM_LOAN_CON does not Granger Cause TERM_LOAN_ISLAMI & 0.0605 & Reject H0 \\
\hline TERM_LOAN_ISLAMI does not Granger Cause TERM_LOAN_CON & 0.0062 & Reject H0 \\
\hline WC_CON does not Granger Cause TERM_LOAN_CON & 0.0437 & Reject H0 \\
\hline TERM_LOAN_CON does not Granger Cause WC_CON & 0.9359 & Accept H0 \\
\hline WC_ISLAMI does not Granger Cause TERM_LOAN_CON & 0.0418 & Reject H0 \\
\hline TERM_LOAN_CON does not Granger Cause WC_ISLAMI & 0.7959 & Accept H0 \\
\hline WC_CON does not Granger Cause TERM_LOAN_ISLAMI & 0.0046 & Reject H0 \\
\hline TERM_LOAN_ISLAMI does not Granger Cause WC_CON & 0.5139 & Accept H0 \\
\hline WC_ISLAMI does not Granger Cause TERM_LOAN_ISLAMI & 0.0082 & Reject H0 \\
\hline TERM_LOAN_ISLAMI does not Granger Cause WC_ISLAMI & 0.2882 & Accept H0 \\
\hline WC_ISLAMI does not Granger Cause WC_CON & 0.2784 & Accept H0 \\
\hline WC_CON does not Granger Cause WC_ISLAMI & 0.2117 & Accept H0 \\
\hline
\end{tabular}

\section{Discussion}

This study was conducted in order to investigate the linkage between loan and deposit pricing of conventional vis-àvis Islamic banks. The findings of the study can be discussed and summarized as follows:

The graphical time series plotting of the rates related to tem loan, working capital loan and fixed deposit of both conventional and Islamic banks showed high positive relationship. The correlation coefficient is also more than 0.90 among these variables. This indicates that, there is sharp linkage between the pricing strategies of both the category of banks.

However, the results of the Z-test partly substantiates the fact found in the graphical and correlation analysis. In case of term loan and working capital loan, the null hypothesis of no difference between rates of conventional and Islamic banks cannot be rejected. Whereas, withregard to fixed and savings deposit rates, the null hypotheses are rejected, indicating difference between the two pricing streams.

The results from the Granger Causality tests were however, inconclusive in finding definite evidence that, pricing of Islamic banking investments is dominated or caused by price set by conventional banking system.

These indicate that, both the category of banks follows the same pricing trend with regard to lending or investment.For Islamic banks which are established with the principle of PLS paradigm this is not the desired mechanism to be followed. While there seems to be existence of high correlation, this research fails to find definite causal relationship.

Bangladesh is the second largest market for the Islamic financial products in the world. Islamic banks established on PLS principle should price their investment on risk sharing basis, independent of the pricing structure followed by conventional banks. 
Finally, this study is not free from limitations. Analysis of the study covered monthly data of less than five years. A more detailed study covering data of wider time span may be conducted tovalidate the results of this study, as well as finding a conclusive causal relationship.

\section{References}

Ahmad, N. and Haron, S. (2002), "Perceptions of Malaysian corporate customers towards Islamic banking products \& services", International Journal of Islamic Financial Services, Vol. 3, No. 4.

Al-Sultan, W. (1999), "Financial characteristics of interest-free banks and conventional banks",PhD dissertation, The University of Wollongong, Wollongong.

Ariss R. T., (2010), Competitive conditions in Islamic and conventional banking: A global perspective, Review of Financial Economics 19 (2010) 101-108.

Asutey, M. (2007). A political economy approach to Islamic economics: Systemic understanding for an alternative economic system. Kyoto Bulletin of Islamic AreaStudies, 1/2, 3-18.

Bakar, M. A. (2010) Broad Distinction between Islamic \& Conventional Banking, Seminar; Malaysia.

Bangladesh Bank (2013) Economic Data (http://www.bangladesh-bank.org/econdata/index.php)

Beck T, Demirgüç-Kunt A, and Merrouche O, (2012), Islamic vs. conventional banking: Business model, efficiency and stability, Journal of Banking and Finance, 37 (2013) 433-447.

Benaissa, N., Parekh, M.P., Wiegand, M., (2005). A growth model for Islamic banking. The McKinsey Quarterly October. http://www.mckinseyquarterly.com/article page.aspx?ar=1694\&L2=10\&L3=51

Bourkhis K. and Nabi M. S. (2013), Islamic and conventional banks' soundness during the 2007-2008 financial crisis, Review of Financial Economics 22 (2013) 68-77.

Chapra, M.U. (1992) Towards a Just Monetary System, Liecester: The Islamic Foundation.

Chong, B. S. and Liu, M. (2005) Islamic Banking: Interest-Free or Interest-Based? AFAANZ Conference. Financial Times, 2011. Islamic Finance (Supplement, May 12).

Gheeraert, L. (2014), Does Islamic finance spur banking sector development? J. Econ. Behav. Organ., http://dx.doi.org/10.1016/j.jebo.2014.02.013

Hasan, M., \&Dridi, J. (2010). The effects of the global crisis on Islamic and conventionalbanks: A comparative study, IMF WP 10/201.

Hearn B, Piesse J, and Strange R., (2012), Islamic finance and market segmentation: Implications for thecost of capital, International Business Review 21 (2012) 102-113.

Iqbal, Z. (1997) Islamic financial systems. Finance \& Development 43, 42-45.

Khan F., (2010), How 'Islamic' is Islamic Banking? Journal of Economic Behavior \& Organization 76; 805-820.

Khan, M.S., Mirakhor, A. (1989) Islamic banking: Experiences in the Islamic Republic of Iran and Pakistan. IMF Working Paper No. WP/89/12, Washington DC: International Monetary Fund.

Khattak, N.A. and Rehman, K.U. (2010), "Customer satisfaction and awareness of Islamic banking system in 
Pakistan”, African Journal of Business Management, Vol. 4, No. 5,pp. 662-71.

Masood, O. and Bora, A. (2009), "Islamic banking: a study of customer satisfaction and preferences in non-countries", International Journal of Monetary Economics and Finance,Vol. 2 Nos 3/4, pp. 261-85.

Mills, P.S., Presley, J.R., 1999. Islamic finance: Theory and practice, London: Macmillan.

Mokhlis, S., SafrahSalleh, H. and Nik Mat, N.H. (2009), "Commercial bank selection: comparison between single and multiple bank users in Malaysia", International Journal of Economics and Finance, Vol. 1 No. 2.

Omer, H. (1992), "The implication of Islamic beliefs and practice on Islamic financial institutions in the UK", $\mathrm{PhD}$ dissertation, Loughborough University.

Rehman, A. A. and Masood, O. (2012),"Why do customers patronize Islamic banks? A case study of Pakistan", Qualitative Research in Financial Markets, Vol. 4, No. 2 pp. 130 - 141.

Safiullah, M. (2010) Superiority of Conventional Banks \& Islamic Banks of Bangladesh: A Comparative Study, International Journal of Economics and Finance. Vol. 2, No. 3.

Thambiah, S., Eze, U.C., Sin Tan, K., Nathan, R.J. and Lai, K.P. (2010), "Conceptual framework for the adoption of Islamic retail banking services in Malaysia”, Journal of Electronic Banking Systems, available at: www.ibimapublishing.com/journals/JEBS/jebs.html

World Bank, (2006) Country brief report: Malaysia. http://siteresources.worldbank.org/inteaphalfyearlyupdate/Resources/550192-1143237132157/malaysiaMarch06.pdf)

Iqbal, M. and Molyneux, P. (2005), Thirty Years of Islamic Banking: History, Performance and Prospects, Palgrave Macmillan, New York, NY.

Rashid, M., Hassan, M.K. and Ahmad, A.U.F. (2009), "Quality perception of the customerstowards domestic Islamic banks in Bangladesh”, Journal of Islamic Economics, Bankingand Finance, Vol. 5 No. 1, pp. 109-31.

Metwally, M. (1996), “Attitudes of Muslims towards Islamic banks in a dual-banking system”,American Journal of Islamic Finance, Vol. 6, pp. 11-17. 